\title{
A Problem Mapping of Public Sector Personnel Management Road Map in Indonesia
}

\author{
Amy Y S Rahayu \\ Faculty of Administrative Sciences \\ Universitas Indonesia \\ Depok, Indonesia \\ amy_soeroso@yahoo.com
}

\author{
Pantius Drahen Soeling \\ Faculty of Administrative Sciences \\ Universitas Indonesia \\ Depok, Indonesia \\ pantiusdrahen@gmail.com
}

\author{
Krisna Puji Rahmayanti \\ Faculty of Administrative Sciences \\ Universitas Indonesia \\ Depok, Indonesia \\ krisnapuji@yahoo.com
}

\begin{abstract}
This study aims to analyze implementation of human resource management in Badan Kepegawaian Negara (BKN) and construct a road map of public sector personnel management in Indonesia based on BKN case. This study uses post positivism and conduct research between 2013 to 2015 . The result finds compensation system does not fulfil equity for its employee based on alignment, competitiveness, contribution, and management aspects. While in the career planning and development absent in goal setting and systematic career management. Career counselling for public sector personnel in BKN also needs improvement in reconstructing structure, goals, effectiveness and support of training needs assessment. Lesson learned from BKN cases support for the public sector personnel management need to formulate and transform into systematic career planning and development, equity of compensation and incentives, and strengthen career counselling functions.
\end{abstract}

Keyword: component; Public Sector Personnel; Human Resource Management; Compensation and Incentives System; Career Counselling; Training Needs Assessment; Planning and Development of Career.

\section{INTRODUCTION}

Public services to citizens is one of government main duty. The government delivers public services through bureaucracy. There are no institutions which able to substitute the role of bureaucracy in delivering public services. The role of the bureaucracy as government personification, its power in information, technical capacity, specialization, and human resources because having worked for a long time period, also its power in the politic make bureaucracy tend to be the single authoritarian institution. This condition makes bureaucracy become one and only institution that has an authority to justify all its activities on behalf of government [1]. In the public sector, the bureaucracy has important rule and function as supporting system in the policy formulation, implementation, and evaluation, and also a direct role in the public service delivery.

Recently, transformation of bureaucracy result in less effective performance without improvement of leadership, public sector personnel's capacity, quality of rule and regulation, and a good control system. Public sector personnel's as implementation element of the bureaucracy become an important aspect not only in the public sector reform but also in the public service delivery. In line with the urgency of the role of the public sector personnel's in the bureaucracy, the greater demand for capacity of the public sector personnel's. The role of public sector personnel's is important because bureaucracy can run its function to maintain sustainability of governance and administration with the only support of dedicated and qualified human resources.

Bureaucracy becomes a dominant actor in the state because it guarantees sustainability of the state [2]. In Indonesia, the bureaucracy still facing challenges and threat to perform its integrity mainly in public service delivery. Corruption is one kind of bureaucracy pathology which hinder government performance. Indonesia get score 34 in the index of corruption perception in 2014 which assign Indonesia in the 107 ranks out of 174 countries [3]. Corruption in the bureaucracy hinders public service delivery, for example, in doing business which eventually results Indonesia in 114 ranks out of 189 countries with score 59/15 [4].

In addition, the quality of services has also become spotlight in the public sector reform in Indonesia. Low quality of public services becomes a major challenge. Low quality of the public sector personnel's in the bureaucracy become one 
of leverage of low quality in its performance. The urgency of improvement to attain equal public sector personnel's quality from top to bottom ladder of management. Therefore, this study aims to analyze the root causes in the bureaucracy, especially in the human resource management aspect which hopefully strengthen public sector reform in Indonesia. This study will take Badan Kepegawaian Negara (BKN) case as focus study. In the end, the implementation of BKN will give basic knowledge and understanding of the problems of human resource management in the Indonesia civil servants.

In the human resource management concept, an organization at least conduct four basic functions. Its function consists of recruitment, placement, training and education, motivation (include compensation, career, and counselling), and maintenance. Support this basic function, Dessler (2013) stated that "process of acquiring, training, appraising, and compensating employees, and of attending to their labor relations, health and safety, and fairness concerns" [5].

In this locus of study, BKN has huge influence to the quality of a public sector personnel as a whole in the government because the role of $\mathrm{BKN}$ is improving public sector personnel quality. Therefore, BKN ethically need to empower its human recourse management in order to be a role model of public sector personnel management in the other institutions. Challenges in the human resources management in $\mathrm{BKN}$ prove that there is a lack of quality in the career planning and development, compensation and incentive system, training needs assessment (TNA) and career counselling. These problems hinder public sector reform, which may become a threat to effectively develop a road map of public sector personnel's management in the bureaucracy.

There are four factual problems in BKN related to human resources management. Firstly, lack of career planning and development cause the need of job formation is not fulfilled. Secondly, lack of career counselling system for employee. Thirdly, lack of analyzes in the training needs assessment. Fourthly, lack of compensation and incentive system. These factual problems urge an analyzes of human resource management in the BKN as a public sector.

The strategic of human resource management, which consist of attracting; developing; maintaining; and motivating, is a fundamental concept of this study [2] [6]. A road map toward human resources management discuss about strategic direction based on the strategic of the human resource management which include attracting in the recruitment and selection; developing career planning and development and training need assessment; maintaining human resources, for example about career counselling; and motivating that related to compensation and incentive system [2] [6].

Therefore, this study aims to analyze the implementation of career planning and development, role of career counseling, training needs assessment, and also compensation and incentive system in BKN. In addition, the result of this study is expected becomes a guidance to develop a road map or strategic management of human resources in the public sectors. Academically, the discussion of this study may enhance future research and deeper discussion in the human resource management in the public sector and human resource as leverage in the public sector reforms. Besides that, the analyzes of human resource implementation in $\mathrm{BKN}$ significant to improve current condition in BKN.

\section{RESEARCH METHODOLOGY}

This study use post positivism approach and qualitative method. Process of data collection through in depth interview and Focus Group Discussion. Deductive method is used to transform from concept into indicators. Data triangulation through internal confirmation from BKN human resource and experts becomes one of step to verify data validity.

\section{RESULTS AND DISCUSSION}

The result of this study show that, firstly, there are challenges and threats in the implementation of career planning and development as part of developing stage in the human resource strategic management. There is inconsistency between career management and career planning which imply a threat of career planning in BKN. BKN has not enacted employee career path based on qualification and competency which result in this inconsistency. Capacity and potency of the employee are not directly linked to career pathway and also career management program in BKN. This condition makes career management difficult to adjust with organization need.

Dealing with these challenges, BKN has compiled a new regulation to manage employee career pathway. However, this effort still has little chance to be effective because current regulation is not yet implemented. Absence of implementation of current regulation become a threat in planning and developing career system. This condition also results in lack of confidence that new regulation will be implemented successfully. Several other research also found that implementation of planning and development of the career system in the public sector also faced many challenges. A research in the judiciary body in Central Jakarta, Sukabumi and Subang in 2003 found the relation between career development and motivation of judges is positive and strong which also reflect different levels of motivation between each region. The conclusion of this study stated that all evidences support that career development still far from expectation [7]. Another research about perception show a different point of view because it found that in Sekretariat Jenderal dan Kepaniteraan Mahkamah Konstitusi Republik Indonesia in 2009, the majority of the employees assume that career development in their office has been implemented perfectly [8].

Secondly, training need assessment as part of development stage also strengthen elaboration of human resource management discussion in BKN. The result found that training needs assessment in BKN currently running without need analyzes in organizational and individual level. Training in the training center based on subjective assessment of the program planner. Therefore, BKN is currently striving to prepare a tool or media for employee e-analysis. The challenge of this effort will emerge because there is no competency standard of the employee.

Thirdly, analysis of career counseling in BKN may enhance discussion about maintaining stage. This study found that counselling service does not focus on career counseling, but tend to focus on helping client which get mental disorders. This 
implies that counselling center does not effectively help employees to maintain their careers or even develop employee career pathway. In addition, counselors who help counseling center are not member of the certified counselor's professional association. Certification of counselors from counselor professional association is important to guarantee their professionalism. Internal rule from Head of BKN and standard operational procedure which manage counselling center have not been formalized in a strong and clear regulation. Therefore, in order to increase the role of counselling center, it is very important to formalize these internal rules in a clear regulation, cooperate with the certified counselors' association to help maintaining the counselling center, and transform counselling center into an instrument and choice of employee to maintain and improve their career.

In overcoming these challenges, BKN need to create some steps. A positive image of counselling center is the very first requirement to build employee trust which reassure employee to harness counselling center. In addition, transformation into a more positive change of counseling center also needs to consider guidance for employees' career counselling in the public sector based on Perka Number 19 Year 2014. A manual model for counselling center also required to support counselling implementation of employee in BKN. Career counselling and development are one of instrument to support employee in order to be able to attain their career goals and maintain chances achieve these goals [9]. A good career development will minimize problems related to the relationship between employee and supervisor about organizational performance [10] This career development also will give positive impact to individual employee because potentially become one of the effort to increase their career positions [11].

Fourthly, analyzes about the compensation system may enhance understanding about current condition of the compensation system in $\mathrm{BKN}$ and motivation stage in human resource management. The result found that equity value in goal or target of the compensation system for civil servant in $\mathrm{BKN}$ or generally in Indonesia civil servant is limited to fulfill internal equity and external equity, while equity for individual employee is not coherent because there is separation between employee payroll and employee incentive. Besides that, equity value in the implementation of the compensation system in Indonesia civil servant is not able to achieve several aspects of equity, such as (1) alignment; position level and working tenure of civil servants in Indonesia currently are not relevant to support alignment aspect because difficult to reflect the relative value of employee position, (2) competitiveness indicates that payroll in the public sector includes in BKN is not competitive compare to the market rate, (3) contributions aspect found a lack of appreciation toward employee performance and competency, (4) management aspect indicates that there is a lack of transparency, especially about data and information in public sector financial ability to payroll allocation.

The difficulty to maintain equity in the compensation system also found in several other researches. In 2012, a research about the compensation system in the Ministry of Employment and Transmigration (Kementerian Tenaga Kerja dan Transmigrasi), DKI Jakarta Province, Gunung Kidul Regency, and The City of Depok found that the compensation system for civil servant in Indonesia has not met equity value and worthiness for civil servants and their family, therefore difficult to increase employee productivity.

Other research also found that compensation system has not met equity value and standard of living. This result found in a research with samples from Sumatera Utara, Jambi, Kepulauan Riau, DKI Jakarta. West Java, Yogyakarta, East Java, East Kalimantan, Gorontalo, Bali, West Nusa Tenggara, East Nusa Tenggara Province [12]. It is very important to consider the balance of equitable external and internal in fulfilling equity aspect. This is suitable with a research about the compensation system for civil servant in Direktorat Jenderal Peraturan Perundang-undangan Ministry of Law and Human Right (Departemen Hukum dan Hak Asasi Manusia) which imply that the implementation of the compensation system is already equal externally but it is not internally [13].

Compensation system is a crucial aspect in the human resource management because it's part of management style which will affect all parts of the organization management as a whole [14]. Compensation become a manifestation of appreciation and incentive as exchange of employee work. Compensation have several functions, such as (1) attract employees (2) retain employees (3) motivate employees (4) compliance with pay laws (5) administrative simplicity and (6) cost effectiveness. This characteristic and function of compensation may become leverage for employee to innovate and love their job. Therefore, BKN effort to fulfill the equity value of compensation system will eventually influence management style and also motivate employees. Eventually, compensation potential to motivate employee in order to maintain good performance while in the process to pursue expected performance of the organization as performance is not only about output but also process [15].

\section{CONCLUSION}

Study about human resource management in BKN which based on developing, maintaining, and motivating perspective found that several challenges hinder its implementation. The implementation of compensation and incentive, career development, training needs assessment, and career counselling in BKN implies that lack of commitment, employee quality, and formal regulation to guide implementation responsible of these challenges.

Therefore, an effort to develop a road map of human resource management need to reflect from implementation of human resource management in $\mathrm{BKN}$ which indicate that a technical guidance based on UU ASN and also an integrated transformation scheme is required. Related to public sector reform, these evidences suggest to urge all public institutions in Indonesia to strengthen political will from top to down ladder of bureaucracy to prevent and overcome lack of implementation performance. Developing and motivating perspective may become an important aspect to leverage commitment of employee and leaders of bureaucracy to transform and change in accordance with public sector reform and road map of human resource management in Indonesia. Therefore, effort to maintain and improve the performance of these aspect need to be prioritized. 


\section{ACKNOWLEDGMENT}

This publication is a preliminary result of a research entitled "Road Map of Public Sector Personnel Management in Indonesia" which funded by DRPM Universitas Indonesia through PITTA Scheme. A grant for grand research which related to several student researches.

\section{REFERENCES}

[1] Du Gay, Paul, ed. The values of bureaucracy. OUP Oxford, 2005

[2] Farazmand, Ali. "Bureaucracy and democracy: a theoretical analysis." Public Organization Review 10.3 (2010): 245-258

[3] Transparency International. "Corruption Perception Index 2014 Transparency International, 2014.

[4] The World Bank Group, 2015

[5] Dessler, Gary. "Human Resource Management-13th ed." (New Jersey: Pearson Education, Inc.). 2013

[6] Robbins, Stephen P., David A. DeCenzo, and Mary K. Coulter Fundamentals of management: essential concepts and applications. Upper Saddle River, NJ: Pearson Prentice Hall, 2008. Noe et all, 2012
[7] Wahyudin. "Analisis Hubungan dan pengaruh perencanaan karir dengan motivasi kerja Hakim pengadilan Negeri kelas 1A, Jakarta Pusat, Pengadilan Negeri kelas 1B Sukabumi dan Pengadilan Negeri kelas II Subang". 2003

[8] Iman Sudirman. "Analisis persepsi pegawai mengenai pengembangan karir pegawai di lingkungan Sekretariat Jenderal dan Kepaniteraan Mahkamah Konstitusi Republik Indonesia”. 2009

[9] Stone, Raymond J. "Human Resources Management". Seventh edition, John Wiley and Sons, Australia. 2010 page 383.

[10] Gilley, Jerry W., Steven A. Eggland, and Ann Maycunich Gilley. Principles of human resource development. Basic Books, 2002.

[11] Gibson, James L. \& John M,Ivancevich. "Organisasi: Prilaku, Struktur, Proses". Erlangga, Jakarta. 1994 page 177.

[12] Pusat Peneltian dan Pengembangan BKN. "Penyusunan Struktur Gaji Pegawai Negeri Sipil. 2006

[13] Juliasman Purba, "Analisis Sistem Penggajian Pegawai Negeri Sipi Pada Direktorat Jenderal Peraturan Perundang-undangan Departemen Hukum dan Hak Asasi Manusia". 2006.

[14] Sibson, Robert Earl. "Compensation". (New York: AMACOM). 1990

[15] Fletcher, C. "Performance Appraisal and Management: The Developing Research Agenda. Journal of Occupatioal and Organizational Psychology, 73, 473-487. 2001. 